\title{
Phenytoin Induced Erythema Multiforme
}

\author{
Dhamodharan Anuranjani, Selvaraj Nitya*, Sivagourounadin Kiruthika \\ Department of Pharmacology, Sri ManakulaVinayagar Medical College and Hospital, Puducherry, INDIA.
}

\begin{abstract}
Phenytoin is conventional antiepileptic drug is effective in the treatment of generalized tonic-clonic seizures but its adverse effects makes its usage limited. We herein present the case of Phenytoin induced Erythema Multiforme. A 65-year-old elderly female presented to our hospital with a 3 days history of itching all over the body, multiple reddish lesions over bilateral arms, forearms, anterior aspect of chest, trunk, bilateral palms and soles. Patient developed skin lesion 1 month after and she started taking phenytoin $100 \mathrm{mg}$ twice a day for left frontal temporal subdural hematoma. Dermatological examination revealed multiple tangloid lesions over the lateral aspect of neck. Phenytoin was discontinued and the skin lesions resolved spontaneously within 2 weeks. The health-care professionals
\end{abstract}

should be aware of such dermatological reactions so that it can be diagnosed and treated early.

Key words: Antiepileptic, Erythema multiforme, Phenytoin.

Correspondence

Dr. Nitya Selvaraj

Associate Professor, Department of Pharmacology, Sri Manakula Vinayagar Medical College and Hospital, Kalitheerthalkuppam-605107, Puducherry, INDIA.

Phone: +91 8489606099

Email: anudhamu8@gmail.com

DOI: 10.5530/jyp.2020.12.98

\section{INTRODUCTION}

The global public health problem in neurological disorder is epilepsy. This affects people of all age groups irrespective of their socioeconomic background and geographic location. This allures to undergo many studies to find out an effective drug to treat. ${ }^{1}$ The conventionally used drug for the control of epilepsy is phenytoin. Since then it is being widely used for control all type of tonic-clonic and complex partial seizures till date. ${ }^{2}$ As phenytoin has wide pharmacokinetic variability and very low threshold for toxicity its use is being limited. ${ }^{3}$ The dermatological adverse reaction reported with the use of phenytoin both in therapeutic and prophylactic dose are urticaria, erythroderma, erythema multiforme (EM), Steven - Johnson syndrome and toxic epidermal necrolysis. ${ }^{4}$ EM is caused by the deposition of lymphohistiocytic inflammatory infiltrate around the blood vessels. which in turn causes degenerative changes in the capillary endothelial cells resulting papillary-dermal edema. ${ }^{5}$ Many literature reviews divulged the causation of EM associated with phenytoin when used in combination with radiation therapy. ${ }^{6-10}$

Here we report a case of 64-year-old elderly female who developed erythema multiforme following the use of phenytoin.

\section{CASE REPORT}

A 65-year-old elderly female presented to the causality department in our hospital with the complaints of itching all over the body, multiple reddish lesions over bilateral arms, forearms, anterior aspect of chest, trunk, bilateral palms and soles for the duration of 3 days. On further evaluation it was revealed that she has been diagnosed to have left frontal temporal subdural hematoma by a private practitioner. The patient was advised to take tablet phenytoin $100 \mathrm{mg}$ twice daily. So, she was taking the tablets for the past 1 month. On examination her vitals were stable. Dermatological examination revealed multiple tangloid lesions over the lateral aspect of neck, few erythromatous papules over anterior trunk, multiple target lesions papules over the flexor and extensor aspect of bilateral forearms (Figure 1), multiple purpuric macules present over anterior aspect of neck region, multiple areas of pinpoint petechiae present bilateral palms and soles. Routine blood investigation was done. The patient was diagnosed as a case of phenytoin induced erythema multiforme. Then she was treated with tablet hydroxyzine $10 \mathrm{mg}$, tablet prednisolone $20 \mathrm{mg}$, liquid paraffin external applications (E/A), momate lotion E/A. After obtaining opinion from a neurosurgeon phenytoin was stopped. As antiepileptic was not required at present. The lesions resolved within 2 weeks and recovered completely without any sequalae. The Naranjo's criteria and (WHO) probability scale were applied to determine the causality for suspected adverse drug reactions. The causality assessment with both scales revealed that adverse reaction due to phenytoin in this case was probable (Table 1 and 2). ${ }^{11,12}$

\section{DISCUSSION}

Phenytoin is useful for all types of epilepsy except petit mal epilepsy. It does not cause sedation. Phenytoin has narrow therapeutic range of 10$20 \mathrm{mcg} / \mathrm{ml} .{ }^{13}$ It has peculiar pharmacokinetic properties, when plasma concentration $<10 \mathrm{mcg} / \mathrm{ml}$ follows first order and further increase in plasma concentration $>10 \mathrm{mcg} / \mathrm{ml}$ saturate metabolic pathway and shifts to zero order elimination. The half-life of phenytoin ranges from 6-24 hrs at plasma concentration $<10 \mathrm{mcg} / \mathrm{ml}$ but increases to $24-60 \mathrm{hrs}$ in plasma concentration $>10 \mathrm{mcg} / \mathrm{ml} .{ }^{14}$ So thereby dose titration must be made at small doses in longer interval. Hence the adverse effects of the phenytoin depend on plasma concentration. In higher dose, zero order pharmacokinetics makes the half-life prolonged leading in to increased toxicity. In low dose toxicity produces hyperplasia of gums, hypersensitivity reactions, hirsutism, hyperglycemia, hydantoin syndrome, osteomalacia, megaloblastic anemia and peripheral neuropathy. In higher plasma concentrations it affects the central nervous system. ${ }^{15}$

The dermatological adverse effects are due to hypersensitivity reaction which is caused by toxic dose of the drug associated with aromatic anticonvulsants. Anticonvulsants are converted to reactive metabolites and induce cytochrome $\mathrm{P} 450$ 3A which produce oxidative reactive 
Table 1: Naranjo Adverse drug reaction probability scale.

\begin{tabular}{|c|c|c|c|c|}
\hline Question & Yes & No & $\begin{array}{l}\text { Don't } \\
\text { know }\end{array}$ & Score \\
\hline $\begin{array}{l}\text { Are there previous conclusion reports on this } \\
\text { reaction? }\end{array}$ & +1 & 0 & 0 & 1 \\
\hline $\begin{array}{l}\text { Did the adverse event appear after the suspect } \\
\text { drug was administered? }\end{array}$ & +2 & 0 & 0 & 2 \\
\hline $\begin{array}{l}\text { Did the adverse reaction improve when } \\
\text { the drug was discontinued, or a specific } \\
\text { antagonist was administered? }\end{array}$ & +1 & 0 & 0 & 1 \\
\hline $\begin{array}{l}\text { Did the adverse reaction reappear when the } \\
\text { drug was re-administered? }\end{array}$ & 0 & 0 & 0 & 0 \\
\hline $\begin{array}{l}\text { Are there alternate causes (other than the } \\
\text { drug) that could solely have caused the } \\
\text { reaction }\end{array}$ & -1 & +2 & 0 & 2 \\
\hline $\begin{array}{l}\text { Did the reaction reappear when a placebo was } \\
\text { given? }\end{array}$ & -1 & +1 & 0 & 0 \\
\hline $\begin{array}{l}\text { Was the drug detected in blood (or other } \\
\text { fluids) in a concentration known to be toxic? }\end{array}$ & +1 & 0 & 0 & 0 \\
\hline $\begin{array}{l}\text { Was the reaction more severe when the dose } \\
\text { was increased or less severe when the dose } \\
\text { was decreased? }\end{array}$ & +1 & 0 & 0 & 0 \\
\hline $\begin{array}{l}\text { Did the patient have a similar reaction to } \\
\text { the same or similar drugs in any previous } \\
\text { exposure }\end{array}$ & 0 & 0 & 0 & 0 \\
\hline $\begin{array}{l}\text { Was the adverse event confirmed by objective } \\
\text { evidence? }\end{array}$ & +1 & 0 & 0 & 1 \\
\hline Total score & & & & 7 \\
\hline
\end{tabular}

Scoring for Naranjo algorithm: $>9$ = definite ADR; $5-8=$ probable ADR; $1-4=$ possible ADR; $0=$ doubtful ADR

\section{Table 2: World Health Organization -Uppsala Monitoring Centre} causality categories.

\begin{tabular}{ll}
\hline Causality term & Assessment criteria \\
\hline Probable & Temporal association present \\
& Pharmacologically definitive event present \\
& De challenge done \\
& Rechallenge not done \\
& No other concomitant drug disease \\
\hline
\end{tabular}

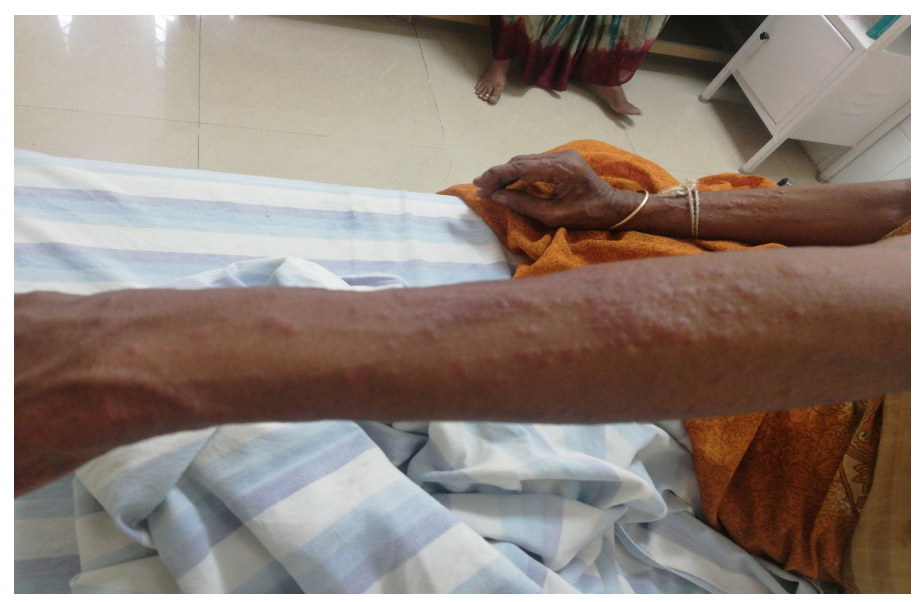

Figure 1: Multiple target lesions papules over the extensor aspect of forearms. intermediate resulting hypersensitivity reactions. These metabolites are excreted from kidney via another hepatic enzyme epoxide hydrolase. ${ }^{16,17}$ Erythema multiforme (EM) is an acute self-limiting, immunological, vesiculobullous disorder primarily affecting the skin and mucous membrane. ${ }^{18}$ Based on the area of involvement it was classified as major and minor. Minor EM involves only the cutaneous region as seen in our study, whereas EM major involves both the mucous membrane and also the cutaneous regions. ${ }^{19}$

The adverse reaction experienced by the elderly female may be due to complex pharmacokinetics and narrow therapeutic index of phenytoin. Thus, the prolong use of phenytoin even in optimal dose can result in toxicity. ${ }^{20}$ which can be explained by non-linear pharmacokinetics exhibited by phenytoin. This clearly shows the unpredictable relationships between serum level of phenytoin and its adverse effects. which can be curbed by frequent dose titration and regular follow up.

\section{CONCLUSION}

This case report about phenytoin toxicity alerts the treating physicians to monitor the patient in long term follow up even if the seizures are under control. This can be overcome to some extent by doing therapeutic drug monitoring if not always at least in the case of any co-morbidities or risk factors associated. This case report highlights the significance of educating both the patient and their bystanders about the common adverse effects and when to report to treating physician. To impede any adverse drug reaction by expeditious identification and treatment.

\section{CONFLICT OF INTEREST}

There are no conflicts of interest.

\section{ABBREVIATIONS}

EM: Erythema multiforme; E/A: External applications; WHO: World Health Organization.

\section{REFERENCES}

1. Thurman DJ, Beghi E, Begley CE, et al. Standards for epidemiologic studies and surveillance of epilepsy. Epilepsia. 2011;52(7):2-26

2. Solanki MS, Kumar K. Usual erratic phenomenon, dramatic outcome: A case report of phenytoin toxicity. BCP. 2013;23(1):81-3.

3. Kumar N, Chakraborty A, Suresh SH, Basappaji S, Betdur AL. Phenytoin induced cerebellar atrophy in an epileptic boy. Indian J Pharmacol. 2013;45(6):636-7.

4. Barbosa LA, Teixeira CR. Erythema multiforme associated with prophylactic use of phenytoin during cranial radiation therapy. Am J Health Syst Pharm. 2008;65(11):1048-50.

5. Borg MF, Probert JC, Zwi LJ. Is phenytoin contraindicated in patients receiving cranial irradiation?. Australas Radiol. 1995;39(1):42-6.

6. Ahmed I, Reichenberg J, Lucas A, Shehan JM. Erythema multiforme associated with phenytoin and cranial radiation therapy : a report of three patients and review of the literature. Int J Dermatol. 2004;43(1):67-73.

7. Micali G, Linthicum K, Han N, West DP. Increased risk of erythema multiforme major with combination anticonvulsant and radiation therapies. Pharmacotherapy. 1999;19(2):223-7.

8. Patterson R, Duykewiez MS, Gonzalzles A, et al. Erythema multiforand Stevens-Johnson syndrome: Descriptive and therapeutic controversy. Chest. 1990;98(2):331-6.

9. Delattre JY, Safai B, Posner JB. Erythema multiiorme and Stevens-Johnson syndrome in patients receiving cranial irradiation and phenytoin. Neurology. 1988;38(2):194-8.

10. Janinis J, Panagos G, Panousaki A, et al. Stevens-Johnson syndrome and epidermal necrolysis after administration of sodium phenytoin and cranial irradiation. Eur J Cancer. 1993;29A:478-9

11. Naranjo CA, Busto U, Sellers EM, Sandor P, Ruiz I, Roberts EA, et al. A method for estimating the probability of adverse drug reactions. Clin Pharmacol Ther. 1981;30(2):239-45.

12. The use of theWHO-UMC System for Standardised Case Causality Assessment Available at: http://www.who-umc.org/Graphics/24734.pdf.

13. Al-Khulaif $A H$, Shujaa AS. Phenytoin induced status epilepticus. Neurosciences. 2010;15(2):131-2. 
14. Sharmaa B, Handaa R, Prakasha S, Nagpala K, Gupt P. Phenytoin toxicity presenting as encephalopathy with fatal outcome: A case report. J Neurol Res. 2013;3(6):184-6.

15. Trevisol-Bittencourt PC, DaSilva VR, Molinari MA, Troiano AR. Phenytoin as the first option in female epileptic patients?. Arq Neuro-Psiquiatr. 1999;57(3B):7846.

16. Man CB, Kwan P, Baum L, Yu E, Lau KM, Cheng AS, et al. Association between HLA-B*1502 allele and antiepileptic drug-induced cutaneous reactions in Han Chinese. Epilepsia. 2007;48(5):1015-8.
17. Dincbas FO, Yörük S, Demirkesen C, Uzel O, Koca S. Toxic epidermal necrolysis after cranial radiotherapy and phenytoin treatment. Onkologie. 2004;27(4):389 92.

18. Hasan S, Jangra J, Choudhary P, Mishra S. Erythema Multiforme: A Recent update. Biomed Pharmacol J. 2018;11(1):167-70

19. Shrihari T G, Shetty SR. Erythema multiforme: A mysterious lesion. Indian J Med Paediatr Oncol. 2018:39(3):363-7.

20. Polman AJ, Werf VDTS, Tiebosch ATMC, Zijlstra JG. Early onset phenytoin toxicity mimicking a renopulmonary syndrome. Eur Respir J. 1998;11(2):501-3.

Article History: Submission Date : 23-10-2020; Revised Date : 02-11-2020; Acceptance Date : 19-11-2020

Cite this article: Anuranjani D, Nitya S, Kiruthika S. Phenytoin Induced Erythema Multiforme. J Young Pharm. 2020;12(4):386-8. 